\title{
DESAIN LOGO DAN MASKOT "DIFABEL KLATEN" SEBAGAI BRAND AWARENESS KAMPANYE SOSIAL PEDULI MASYARAKAT DISABILITAS DI KLATEN, JAWA TENGAH
}

\author{
Yulianto Hadiprawiro \\ Program Studi Desain Komunikasi Visual, \\ Fakultas Bahasa dan Seni Universitas Indraprasta PGRI \\ Jl. Nangka 58 Tanjung Barat, Jakarta Selatan, 12530
}

\begin{abstract}
Abstrak
Hari Disabilitas Internasional (HDI) merupakan momentum difabel-difabel di dunia untuk menunjukkan eksistensinya. Organisasi-organisasi difabel melakukan aksi-aksi kecil di wilayahnya untuk merayakan HDI. Tidak terkecuali organisasi difabel di Kabupaten Klaten, yang tergabung dalam Difabel Klaten, melakukan rangkaian aksi untuk memperingati HDI Klaten 2017. Dalam rangkaian acara peringatan ini, Difabel Klaten membutuhkan logo dan maskot yang mewakili identitas dari kearifan lokal, semangat juang dan optimisme. Tulisan ini membahas tentang desain logo dan maskot sebagai brand awareness kampanye sosial peduli masyarakat disabilitas. Diharapkan dengan adanya desain logo dan maskot ini akan menggerakkan masyarakat untuk lebih mengenal dan mengingat aktivitas Difabel Klaten yang mendukung HDI Klaten 2017.
\end{abstract}

Kata Kunci: Kampanye Sosial, Desain Logo dan Maskot, Difabel.

\section{Logo And Mascot Design Of "Difabel Klaten" As A Brand Awwareness To Social Campaign For Caring The People With Disabilities In Klaten, Central Java}

\begin{abstract}
International Day of People with Disability is a moment for the people with disabilities to perform their existance in the society. Similar to many of organizations of people with disabilities in the world, an organization in Klaten, Central Java, Indonesia, called "Difabel Klaten", held several actions and campaign to celebrate the International Day of People with Disabilities (HDI) Klaten 2017. "Difabel Klaten" requires a logo and mascot design that represents the identity of local wisdom, spirit of struggling, and optimism. This paper discusses about mascot design of Difabel Klaten as a brand awareness social campaign for caring the people with disabilities in Klaten, Central Java. Hopefully this logo and mascot design will bring brand awareness and remindings to society about The Difabel Klaten's activities supporting HDI Klaten 2017.
\end{abstract}

Keywords : Social Campaign, Logo and Mascot Design, Difabel. 


\section{PENDAHULUAN}

Difabel merupakan kepanjangan Different Ability People atau penyandang disabilitas. Penyandang Difabel memiliki daya juang dari sebelum adanya UndangUndang (UU) nomor 4 tahun 1997 tentang Penyandang Cacat untuk memenuhi kebutuhan haknya akan pelayanan publik. Berbagai langkah advokasi dilakukan guna tercapainya kesetaraan dalam menjalani kehidupan difabel dengan non-difabel. Dalam usaha advokasi tersebut, penyandang difabel nampaknya membutuhkan media komunikasi visual termasuk identitas visual untuk mendapatkan kesadaran masyarakat. Salah satu upaya advokasi adalah dengan aktif dalam kegiatan Hari Disabilitas Internasional (HDI). HDI merupakan momentum difabel-difabel di dunia untuk menunjukkan eksistensinya.

Organisasi-organisasi difabel melakukan aksi-aksi kecil di wilayahnya untuk merayakan HDI. Kebanyakan mereka membuat kampanye-kampanye untuk menyuarakan hak mereka sebagai difabel. Seperti diskriminasi, stigma, aksesibilitas. Tidak terkecuali difabeldifabel di Kabupaten Klaten. Mereka membuat sebuah kesepakatan untuk menggunakan brand 'Difabel Klaten' sebagai nama yang dipakai dalam HDI 2017. Difabel Klaten merupakan gabungan dari beberapa organisasi difabel di Kabupaten Klaten, yang bergerak untuk merayakan HDI sebagai salah satu momentum untuk menyuarakan kesetaraan. Dalangnya adalah Persatuan Penyandang Disabilitas Klaten (PPDK) dan Forum Komunikasi Masyarakat Peduli Difabel (FKMPD) Klaten.

Dari hasil observasi awal terlihat bahwa belum ada perancangan materi kampanye untuk hari besar yang mereka rayakan setiap tahunnya, yaitu pada 3 Desember 2017. Melihat hal tersebut, sebagai langkah advokasi untuk memperjuangkan hak-hak difabel di Hari Difabel Internasional, maka perlu adanya perancangan identitas visual guna membangun brand awareness difabel Klaten berupa logo yang berbasis karakter visual yang mengusung gerakan peduli masyarakat terhadap penyandang disabilitas.

\section{Kajian teori}

Membangun brand awareness melalui logo dan maskot karakter

Menurut Rochaety dan Tresnati (2005:35) Brand awareness adalah kemampuan seseorang pelanggan untuk mengingat merek tertentu atau iklan tertentu secara spontan atau setelah dirancang dengan kata-kata kunci. Kesadaran ini digunakan sebagai salah satu indikator efektivitas pemasaran. Definisi-definisi para ahli mengenai brand awareness dapat ditarik simpulan bahwa brand awareness merupakan tujuan umum komunikasi pemasaran, adanya brand awareness yang tinggi diharapkan kapanpun kebutuhan kategori muncul, brand tersebut akan dimunculkan kembali dari ingatan yang selanjutnya dijadikan pertimbangan berbagai alternatif dalam pengambilan keputusan. Brand awareness menunjukkan pengetahuan konsumen terhadap eksistensi suatu brand. Rochaety dan Tresnati (2005:35) menambahkan peran brand awareness dalam ekuitas brand (nilai brand) tergantung pada tingkat pencapaian kesadaran dalam benak konsumen. Brand awareness dapat dibangun dan diperbaiki melalui cara-cara berikut:

1. Pesan yang disampaikan oleh suatu brand harus mudah diingat oleh konsumen.

2. Pesan yang disampaikan harus berbeda dengan produk lainnya serta harus ada hubungan antara brand dengan kategori produknya. 
3. Memakai slogan atau jingle lagu yang menarik sehingga membantu konsumen mengingat brand.

4. Jika suatu brand memiliki simbol, hendaknya simbol tersebut dapat dihubungkan dengan brandnya.

5. Perluasan nama brand dapat dipakai agar brand semakin diingat konsumen.

6. Brand awareness dapat diperkuat dengan memakai suatu isyarat yang sesuai dengan kategori produk, brand, maupun keduanya. Melakukan pengulangan untuk meningkatkan pengingatan, karena membentuk ingatan adalah lebih sulit dibanding membentuk pengenalan.

Melalui pernyataan tersebut, ternyata simbol termasuk ke dalam faktor yang dapat membangun brand awareness. Simbol dari suatu brand dapat berupa logo maupun karakter/maskot. Tulisan ini mencoba untuk menggabungkan keduanya dimana logo sekaligus karakter dirancang untuk membangun brand awareness dari Difabel Klaten melalui acara HDI 2017.

Entitas apapun baik perusahaan, Lembaga, komunitas, forum, dan lainnya hendaknya memiliki logo seperti yang dinyatakan oleh Hardy (2011: 3) mengenai logo "A logo is a graphic identifier that is used to visually communicate anything that requires to be identified. It helps the brand set itself apart from the competition-you don't see the Golden Arches and think of Burger King. And yet logos are not limited to commercial endeavorscharitable organizations, campaigns, even individuals can use logos to identify themselves"

Logo merupakan suatu ikon visual yang mempunyai dua fungsi dasar bagi merek yaitu fungsi identifikasi dan fungsi diferensiasi. Ada beberapa tipe logo yang dibuat dari nama entitas, disajikan dalam bentuk yang unik, sampai dengan yang abstrak yang mungkin tidak ada hubungannya dengan nama perusahaan maupun aktivitasnya secara langsung (Farhana, 2012).

Jika disimpulkan dan dihubungkan dengan desain karakter, maka untuk dapat membangun Brand awareness, diperlukan desain karakter yang mudah diingat dan dapat dihubungkan dengan brand-nya. Dalam mendesain karakter atau kadang disebut maskot, perancang dapat mempertimbangkan "design style" apakah bentuk sederhana ataupun kompleks, "motion alignment" seperti berjalan, berlari dan lainnya, dan "regional feature" (Lin, R., Lin, P. C., \& Ko, K. J., 1999: 117).

\section{HASIL DAN PEMBAHASAN}

\section{Perancangan Logo dan maskot Difabel Klaten dalam rangka HDI 2017}

Tahapan perancangan logo Difabel Klaten meliputi:

1. Me-review kegiatan HDI 2016 melalui foto sebagai pengetahuan awal mengenai acara tersebut.

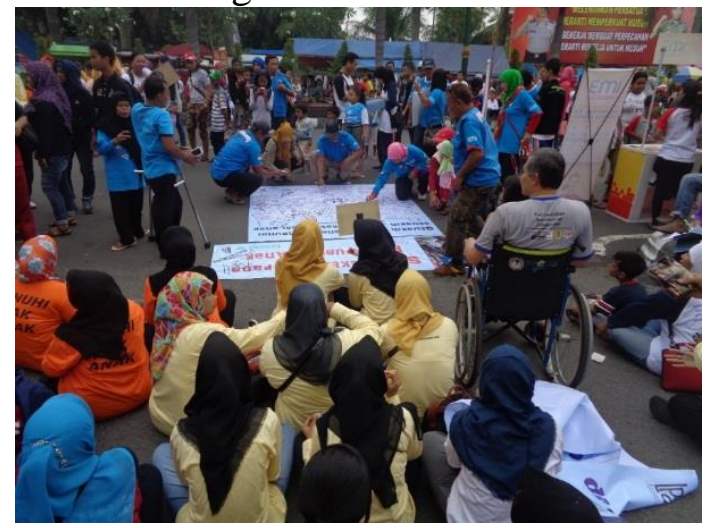

Gambar 1. Suasana Kegiatan Acara HDI 2016 di Klaten

Sumber: Dokumen Difabel Klaten 


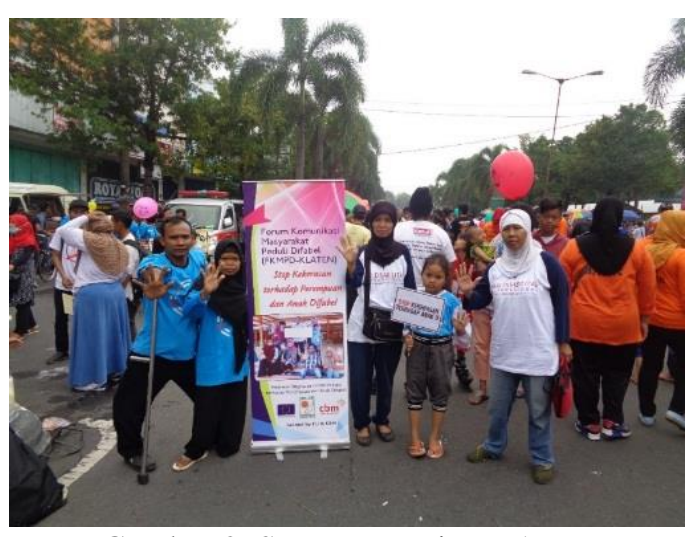

Gambar 2. Suasana Kegiatan Acara HDI 2016 di Klaten

Sumber: Dokumen Difabel Klaten

\begin{tabular}{|c|c|}
\hline $\begin{array}{l}\text { Tema } \\
\text { acara: }\end{array}$ & $\begin{array}{l}\text { "Menuju Masyarakat Inklusif, Tangguh, dan Berkesinambungan" } \\
\text { | Tema ini menyerap ide tema nasional yang akan diangkat pada } \\
\text { HDI Klaten } 2017 \text {. }\end{array}$ \\
\hline $\begin{array}{l}\text { Isu krusial } \\
\text { yang } \\
\text { diangkat: }\end{array}$ & $\begin{array}{lllll}\text { Aksesbilitas dan } & \text { Kebersamaan yang akan mewujudkan } \\
\text { Inklusifitas. } & & & & \\
\end{array}$ \\
\hline $\begin{array}{l}\text { Target } \\
\text { audiens: }\end{array}$ & $\begin{array}{l}\text { semua kalangan masyarakat, tidak terbatas pada usia, gender, dan } \\
\text { status sosial. Karena orang-orang di CFD sangat beragam. }\end{array}$ \\
\hline $\begin{array}{l}\text { Tanggal } \\
\text { dan tempat } \\
\text { acara: }\end{array}$ & $\begin{array}{l}\text { Minggu, } 3 \text { Desember } 2017 \text { di RSPD Klaten (di depan alun-alun } \\
\text { Klaten) }\end{array}$ \\
\hline $\begin{array}{l}\text { Rangkaian } \\
\text { acara: }\end{array}$ & $\begin{array}{l}\text { 1. Relawan Sampah } \\
\text { Berangkat dari } 3 \text { titik di lokasi paling luar CFD, menuju ke } \\
\text { tengah di wilayah RSPD Klaten. Kegiatannya berupa } \\
\text { memungut sampah yang berserakan. } \\
\text { 2. Demo Kursi Roda (berbentuk Atraksi, aksi show off } \\
\text { menggunakan kursi roda) } \\
\text { Dilakukan di sekitar RSPD. } \\
\text { 3. Kelas Bahasa Isyarat } \\
\text { Dilakukan di sekitar RSPD. } \\
\text { 4. Demo IT oleh teman-teman Netra } \\
\text { Dilakukan di sekitar RSPD } \\
\text { 5. Sensifitas Difabel } \\
\text { Dilakukan di sekitar RSPD } \\
\text { 6. Hiburan sekaligus Penutupan } \\
\text { Ini dilakukan di halaman depan RSPD, karena mengingat } \\
\text { acara CFD telah selesai, dan diperkirakan akan diadakan } \\
\text { acara di latar RSPD. }\end{array}$ \\
\hline $\begin{array}{l}\text { Yang harus } \\
\text { dilakukan: }\end{array}$ & $\begin{array}{l}\text { Membuat logo dan maskot Difabel Klaten untuk HDI Klaten } \\
2017\end{array}$ \\
\hline
\end{tabular}




\begin{tabular}{|c|c|}
\hline Tujuan: & $\begin{array}{l}\text { Membangun brand awareness difabel Klaten melalui acara HDI } \\
\text { Klaten } 2017\end{array}$ \\
\hline $\begin{array}{l}\text { Inspirasi/ } \\
\text { referensi: }\end{array}$ & $\begin{array}{l}\text { Warna yang bisa dibuat sebagai identitas adalah: Merah, Biru, } \\
\text { atau Hijau, dengan melambangkan keberanian, semangat dan } \\
\text { terus menerus untuk aktif. } \\
\text { Sebagai materi tambahan, ikon yang mungkin bisa diambil di } \\
\text { Klaten adalah: Bunga, Lurik (pada Batik), Dalang, Wayang, } \\
\text { Air/Umbul. }\end{array}$ \\
\hline $\begin{array}{l}\text { Media } \\
\text { yang } \\
\text { pernah } \\
\text { ada: }\end{array}$ & 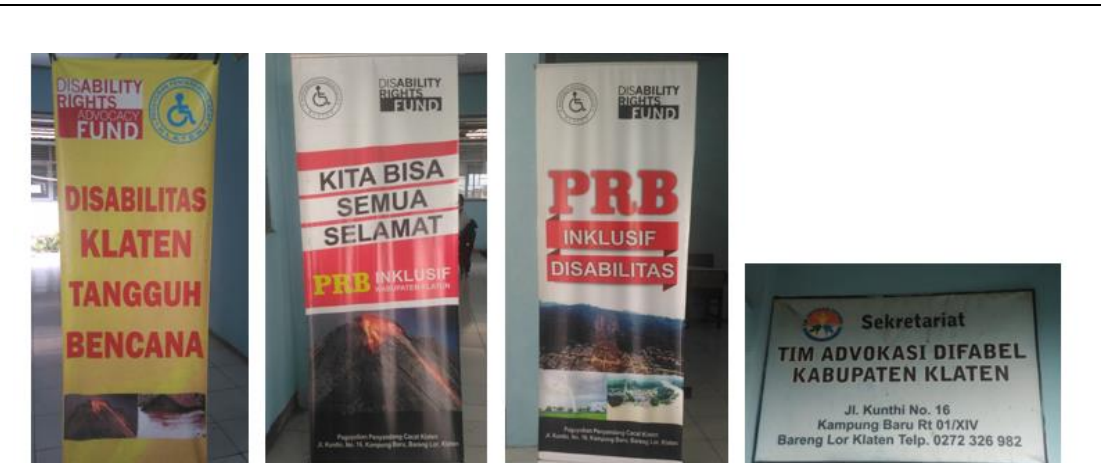 \\
\hline $\begin{array}{l}\text { Suasana } \\
\text { Car Free } \\
\text { Day Alun- } \\
\text { alun } \\
\text { Klaten: }\end{array}$ & 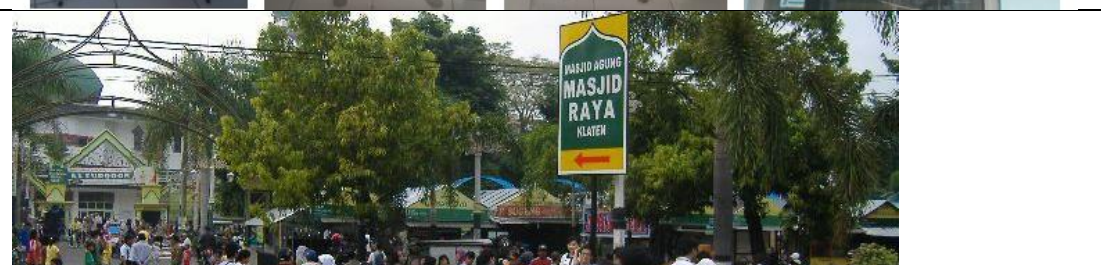 \\
\hline & 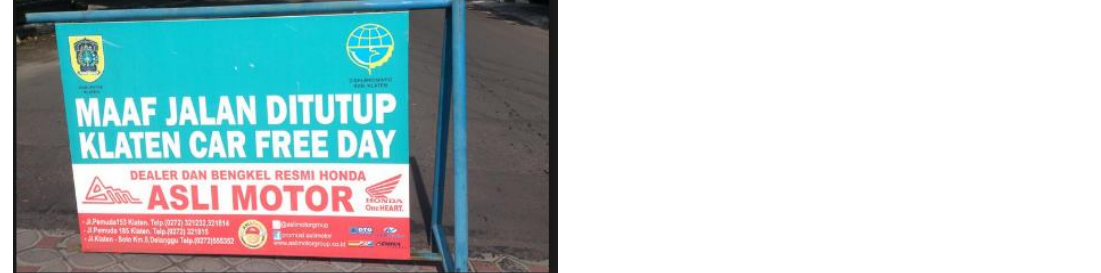 \\
\hline
\end{tabular}

3. Brainstorming ide

Langkah selanjutnya setelah mereview kegiatan HDI tahun lalu (2016) adalah brainstorming ide guna menemukan keyword, keyvisual, konsep visual (gaya visual, ilustrasi, warna, huruf). Tahap ini dilakukan dengan berdiskusi sambil membuat mind mapping:

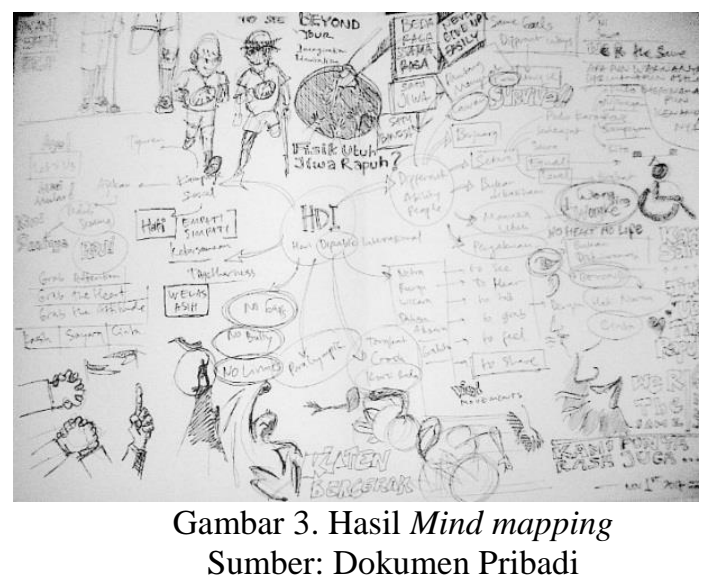


4. Membuat moodboard

Keyword, keyvisual telah ditentukan setelah proses brainstorming. Langkah selanjutnya pembuatan moodboard. Dalam merancang desain logo untuk acara HDI 2017 di Klaten, dibuat moodboard yang terdiri dari warna-warna, foto dan ilustrasi gambar yang berkaitan dengan Klaten, profil target audiens, tempat acara, dan simbol difabel. Sumber gambarnya didapat dari Difabel Klaten maupun dokumentasi pribadi dan internet. Bentuk Moodboard untuk perancangan dapat dilihat pada gambar di bawah ini:

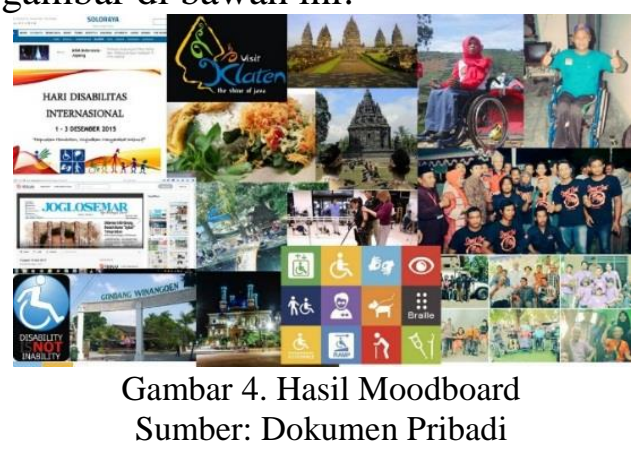

5. Membuat konsep perancangan logo HDI 2017:

Berdasarkan pada bahwa dalam membangun brand awareness bisa dilakukan melalui simbol yang mudah diingat dan berhubungan dengan entitas yang diwakilinya, serta mempertimbangkan bahwa HDI 2017 adalah sebuah acara tahunan dimana Acara/ event pada umumnya biasanya menggunakan maskot/ karakter, maka desain logo Difabel Klaten untuk HDI 2017 dirancang berbasis karakter guna membangun brand awareness Difabel Klaten. Konsep perancangan materi kampanye Difabel Klaten untuk HDI 2017 mewakili identitas dari kearifan lokal, semangat juang dan optimisme yang tertuang dalam kata kunci terpilih: "Difabel Klaten bisa!" dengan ilustrasi karakter mengadopsi bentuk identitas wayang yang merupakan salah satu ciri khas kota Klaten untuk merepresentasikan bahwa peserta HDI berasal dari Klaten. Bentuk karakter menunjukkan tangan dengan jempol ke atas, semakin memperkuat imagi dari tagline "Difabel, Kudu Iso!" yang artinya, Difabel harus bisa untuk bersatu, dan bergerak tanpa memandang dari mana organisasinya, apa jenis ke-difabel-annya. Bentuk simple dari kursi roda merepresentasikan tentang kekuatan Difabel untuk terus maju. Tagline "Difabel Klaten Bisa!" merupakan ajakan untuk masyarakat Difabel Klaten menjadi semakin tangguh, dengan warna merah yang berarti semangat, Difabel Klaten diajak untuk bisa, dalam mengadvokasi dirinya. Memberikan pengaruh kepada khalayak umum untuk dapat setara antara non-difabel dengan difabel.

6. Membuat sketsa

Dengan berdasar pada konsep perancangan kemudian dibuat sketsa manual tangan beberapa alternatif:

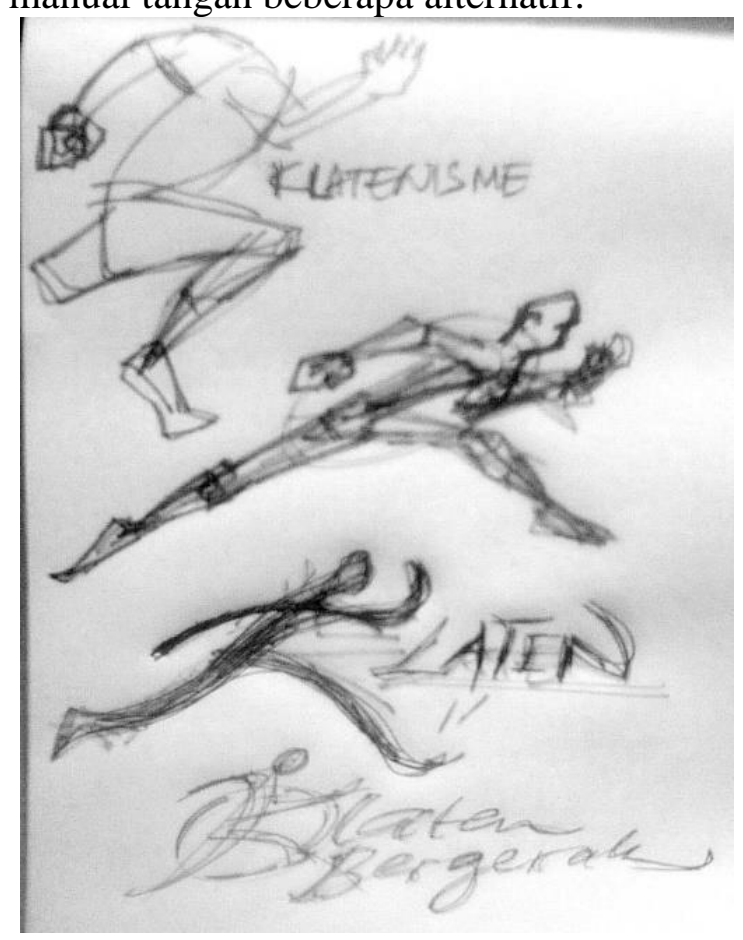



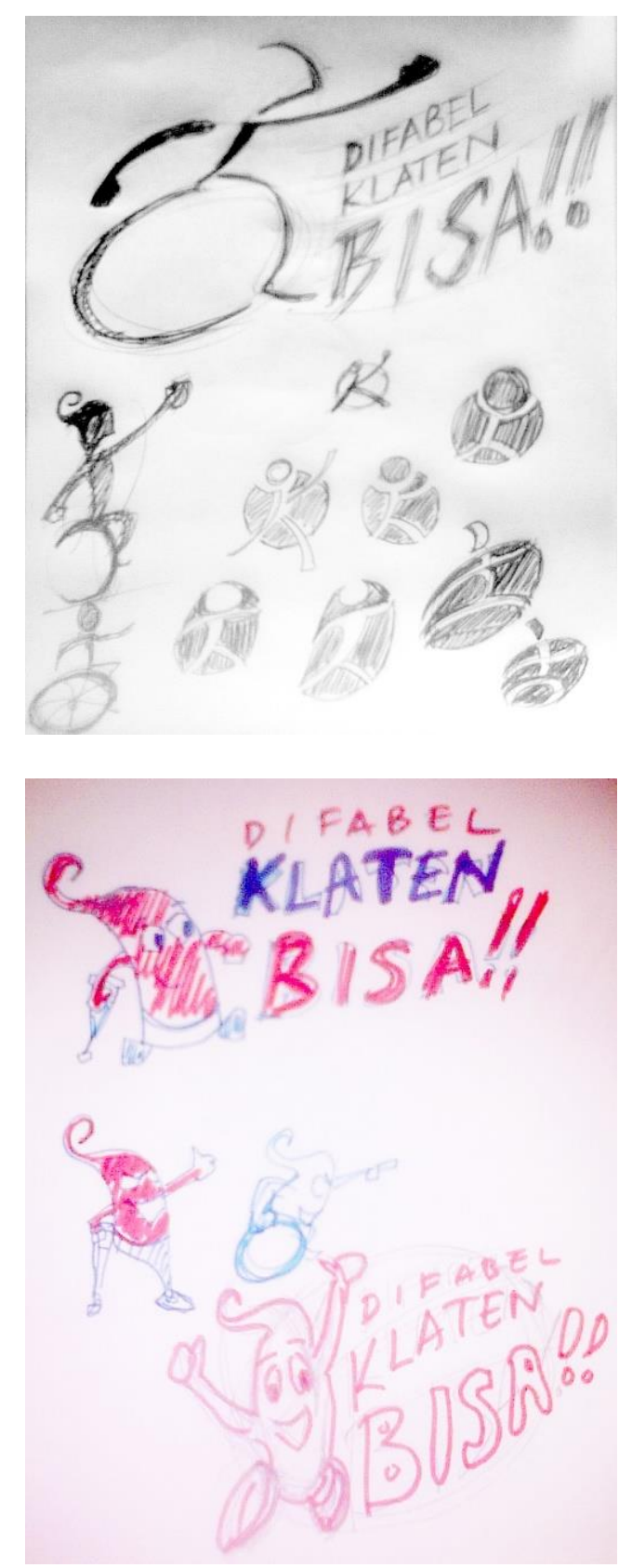

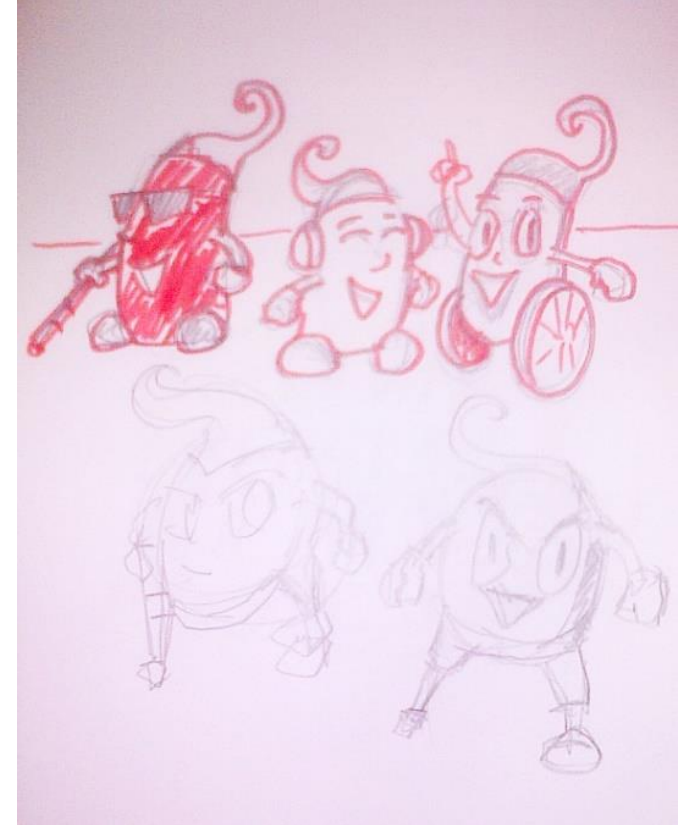

Gambar 5. Hasil Sketsa Manual Sumber: Dokumen Pribadi

7. Mengerjakan digitalisasi desain dan alternatif desain

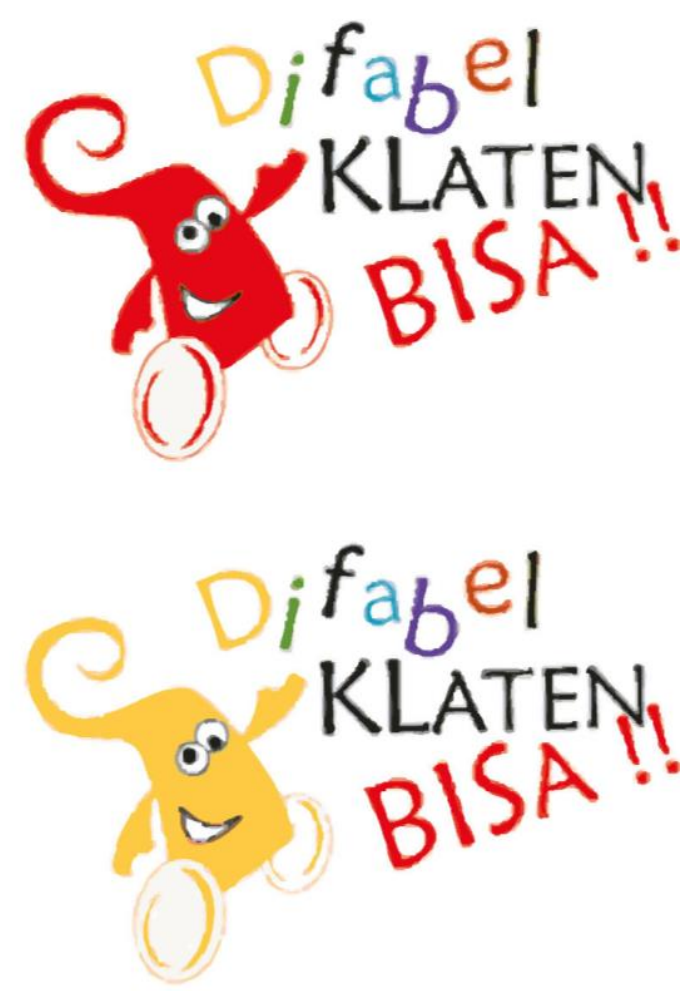




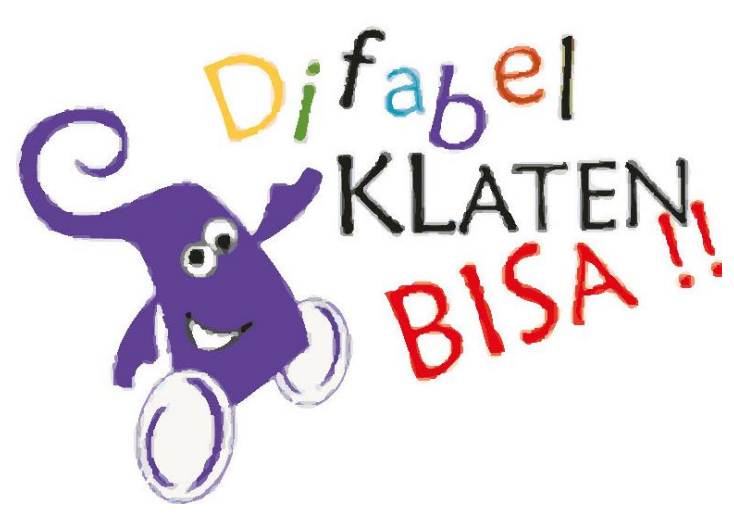

Gambar 6. Desain Logo alternatif 1 Sumber: Dokumen Pribadi

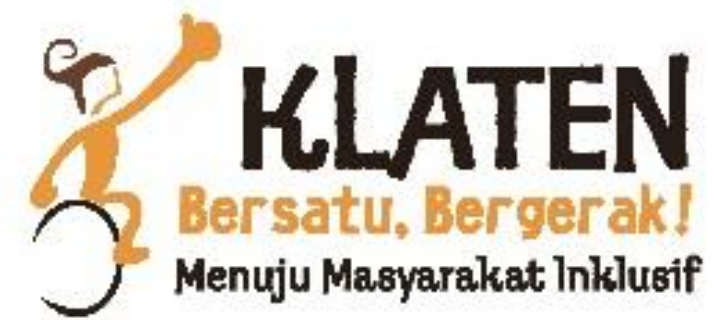

Gambar 7. Desain logo alternatif 2 Sumber: Dokumen Pribadi

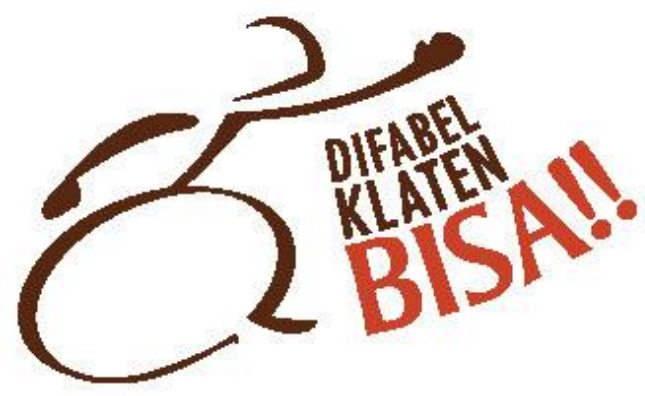

\section{Hari Disabilitas Internasional (HDI) 2017}

Gambar 8. Desain logo alternatif 3 Sumber: Dokumen Pribadi

8. Evaluasi dan Revisi desain final Hasil diskusi dengan Difabel Klaten mengenai desain yang sudah dibuat mengalami revisi desain. Visualisasi logo dan karakter yang muncul pada logo alternatif 1 terinspirasi dari elemen kursi roda, tuna rungu, tuna netra, dsb. yang mewakili keragaman disabilitas yang ada. Namun desain ini dianggap terlalu banyak warna terang sehingga terkesan meriah ceria, kekanak-kanakan, dan masih kurang representatif untuk segmen yang dituju yaitu kalangan masyarakat lokal Klaten yang pada umumnya adalah remaja dewasa. Oleh karena itu, maka desain logo karakter yang dipilih oleh Difabel Klaten ialah alternatif 2 dan 3, dengan logo karakter utamanya dikembangkan dari alternatif 1 dengan perubahan warna.

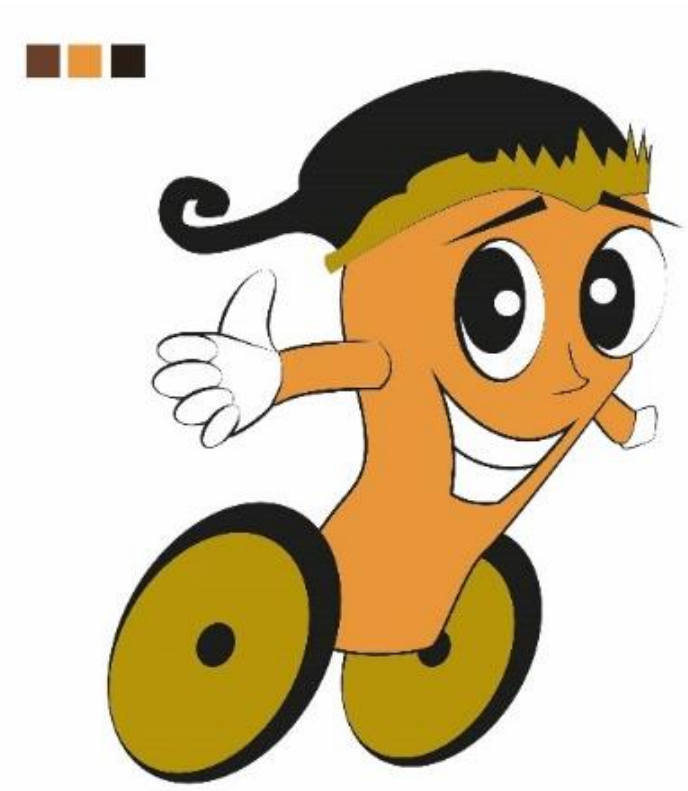

Gambar 9. Karakter Maskot Terpilih Sumber: Dokumen Pribadi 


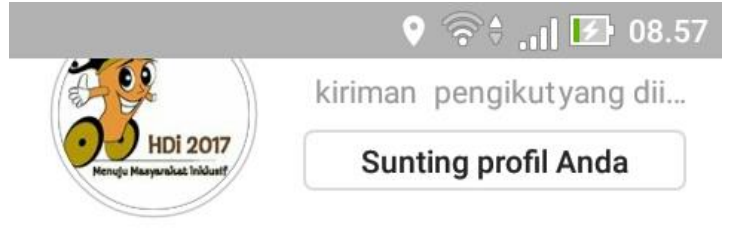

Difabel Klaten

Difabel Klaten berinisiasi mengadakan peringatan HDI 2017. Merupakan alun resmi untuk promosi dalam peringatan HDI Klaten 2017

www.facebook.com/HDIKlaten/

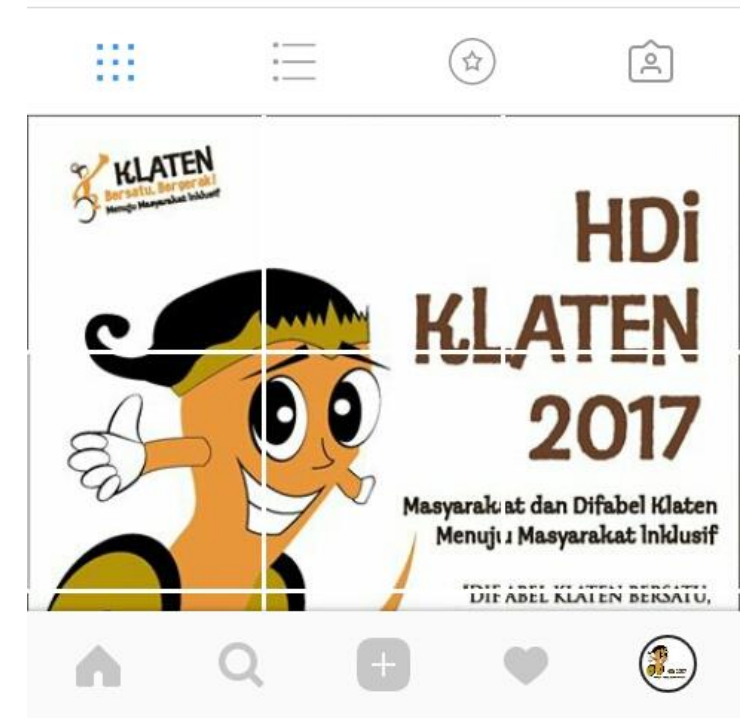

Gambar 10. Mozaik Instagram Sumber: Instagram Difabel Klaten

\section{SIMPULAN}

Dalam membangun brand awareness bagi entitas tertentu dapat dilakukan melalui simbol yang mudah diingat dan berhubungan dengan entitas tersebut. Logo dan maskot Difabel Klaten untuk HDI Klaten 2017 ini dirancang dengan menerapkan kata kunci dan visual kunci yang berkaitan dengan difabel dan ciri khas Klaten Jawa Tengah. Proses perancangan logo dan maskot diawali dari brainstorming ide, yang kemudian diwujudkan dalam pemetaan pikiran atau mind mapping. Dari Mind mapping akan dihasilkan kata kunci. Kata kunci yang ada dicoba divisualkan dan dikumpulkan sampai menjadi referensi untuk menyusun kumpulan gambar yang dinamakan Mood Board. Tujuan dari penyusunan moodboard adalah untuk menghasilkan visual kunci, yang kemudian berkembang menjadi elemen visual dan gaya visual dalam perancangan.

Perancangan tidak terlepas dari kesepakatan perancang dengan pihak entitasnya. Dalam kasus ini yakni logo Difabel Klaten untuk HDI Klaten 2017 oleh Difabel Klaten maka perancangan logo yang tepat ialah berbasis karakter dan maskot sebagai daya tarik visual dengan tujuan agar brand awareness Difabel Klaten dapat terbangun melalui citra yang dekat akrab dengan audiensnya. Dengan konsep dasar mengangkat kearifan lokal, semangat juang dan optimisme. Diharapkan dengan adanya desain logo dan maskot ini akan menggerakkan masyarakat untuk lebih mengenal dan mengingat aktivitas Difabel Klaten yang mendukung HDI Klaten 2017.

\section{DAFTAR PUSTAKA}

Buku

Dawami, A. K. (2017). Logo sebagai Komunikasi Visual dari Identitas Organisasi Tuli. Jurnal Magenta SMTK Trisakti Vol. 2 No. 1. Jakarta: LPPM STMK Trisakti

Farhana, M. (2012) Brand elements lead to brand equity: Differentiate or die. Information Management and Business Review, 4(4), 223-233.

Hardy, Gareth. (2011). Smashing logo design: The art of creating visual identities. Chichester, John Willey and Sons Ltd. 
Lin, R., Lin, P. C., \& Ko, K. J. (1999). A study of cognitive human factors in mascot design. International Journal of Industrial Ergonomics, 23(1-2), 107-122.
Rahayu, S. (2014). Untuk Apa Seni? pada artikel Desain dan Ruhnya Kini. Bandung: Matahari. 